\title{
Dynamic response of biofilm to pipe surface and fluid velocity
}

\author{
T.E. Cloete, D. Westaard and S.J. van Vuuren
}

\section{Introduction}

Numerous research efforts have focused on the development of biofilms (Costerton et al., 1995; Cloete, et al., 1998). MIC is caused by the presence of bacteria in water systems, especially by bacterial biofilms and to prevent this, such bacterial biofilms must be removed. Five mitigation approaches are currently followed: (i) bacteria are chemically killed by application of bactericidal compounds, termed biocides, at lethal doses, (ii) biofilms are dispersed by dispersants, (iii) biofilms are removed physically by a variety of processes, (iv) the biofilm structure is weakened by enzymes or chelants, and (v) planktonic bacterial numbers are controlled by ultraviolet light (Cloete et al., 1998).

However, in order to be more effective in the control of biofouling, it is also very important to identify the growth conditions that are less favorable for microbial activity and biofilm formation. Biofilms are subjected to fluid shear effects, including detachment caused by flowing water (Lawrence et al., 1995; Vieira et al., 1993). Detachment was classified into four categories by Bryers, (1988) i.e. erosion; sloughing; abrasion and grazing. Trulear and Characklis (1982) found that detachment increases with fluid velocity and mass of biofilm. When the shear stress decreased, it had no effect on detachment. Peyton (1996) studied erosion and concluded that detachment is not affected by the shear stress. Understanding the dynamic response of biofilms to various flow velocities could lead to a better understanding of how flow velocity influences the growth and adhesion of the biofilm and whether it is possible to decrease biofilm formation and/or increase detachment, by manipulating flow velocities.

The main objective of this study was therefore to monitor biofilm development and to study the effect of fluid velocity on biofilm formation on different piping materials used in potable water distribution systems.

\section{Materials and methods}

\section{Evaluation of fluid velocity on biofilm formation}

To test the effect of velocity on the growth of biofilm, a Roto-Scope was designed and built to imitate the flow conditions in potable water distribution systems. Two sets of pipe sections were made in order to test more than one velocity during the test period. 


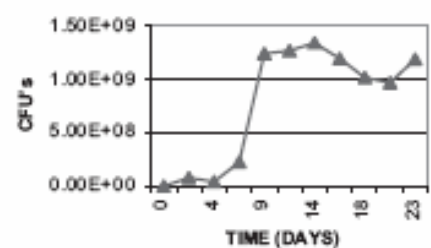

Figure 1 Biofilm growth on asbestos cement

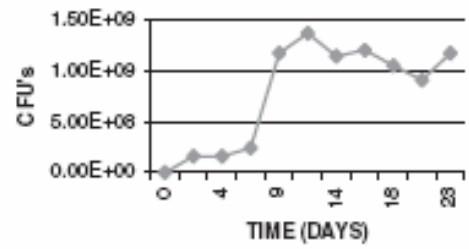

Figure 3 Biofilm growth on casted castiron

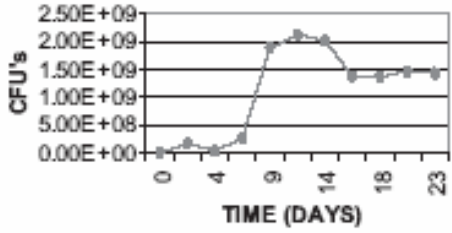

Figure 2 Biofilm growth on PVC

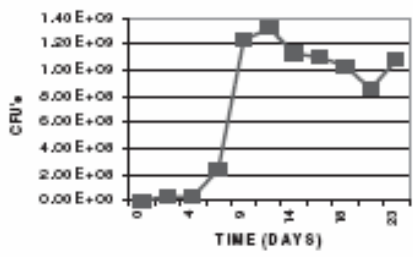

Figure 4 Biofilm growth on galvanized steel

The first set, was fastened to a $100 \mathrm{~mm}$-diameter pulley and the second set was fastened to a $76 \mathrm{~mm}$ diameter pulley. The result of this configuration was that the first set rotated at a much higher angular velocity than the second set. Thus two different flow conditions were simulated simultaneously at room temperature $\left(16-20^{\circ} \mathrm{C}\right)$. Four different piping materials were used to test the response of biofilm growth to fluid velocity i.e.: asbestos-cement $(10 \mathrm{~mm}$ thick); cast iron in a red epoxy coating (6 mm thick); galvanized steel (4 mm thick) and PVC (2 mm thick). The following analysis were conducted on the biofilm: i) DAPI staining and UV-light microscopy (Wolfaardt et al., 1991); ii) determination of the number of culturable cells (Cloete and Jacobs, 2001).

\section{Results and discussion}

Biofilm formation took place on all piping surfaces in a potable water distribution system (Figures 14). There was no significant difference in the bacterial colonization rates on the different surfaces, irrespective of the type of material (Figures 1-4). The yield measured as the total number of viable cells in the biofilm did however differ, with the cfu being the highest on the PVC piping and the lowest on the galvanized steel piping (Figures 1-4). The number of cfu reached a maximum between 9-10 days after which the cfu started to level off somewhat and fluctuated for the remainder of the study period.

Increased flow in the system resulted in a specific detaching velocity, where the formation of biofilm was overcome (Figures 7-8). These results are in agreement with that of Trulear and Characklis (1982) and Wolfaardt and Cloete (1992). Most of the time these detaching velocities were not the highest velocities tested.

The range of detaching velocities were between $\pm 3 \mathrm{~m} \cdot \mathrm{s}^{-1}$ and $4 \mathrm{~m} \cdot \mathrm{s}^{-1}$ (Figures 7-8). A flow velocity within this range would thus be ideal for achieving reduced biofilm growth in potable water distribution systems.

\section{Conclusions}

Increased velocity in the system resulted in a specific detaching velocity, where the formation of biofilm was limited. Most of the time these detaching velocities were not the highest velocities tested. The range of detaching velocities were between $\pm 3 \mathrm{~m} . \mathrm{s}^{-1}$ and $4 \mathrm{~m} . \mathrm{s}^{-1}$. A flow velocity within this range would thus be ideal for achieving reduced biofilm growth in a distribution system. 


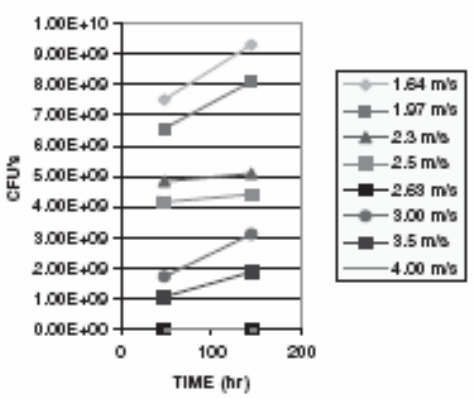

Figure 5 Total viable aessile bacteria on PVC

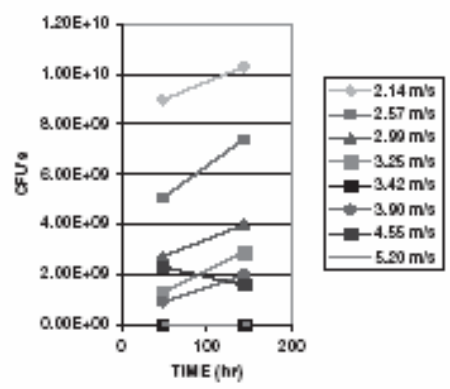

Figure 7 Total viable sessile bacteria on asbestoe cement

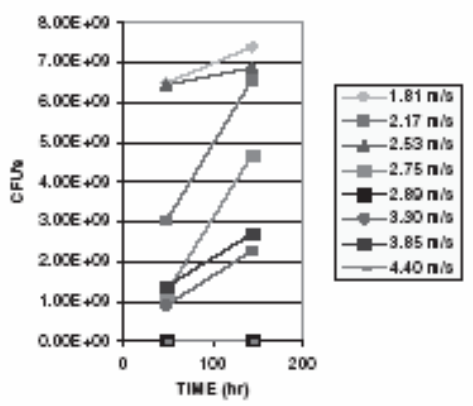

Figure 6 Total viable sessile bacteria on coated castiron

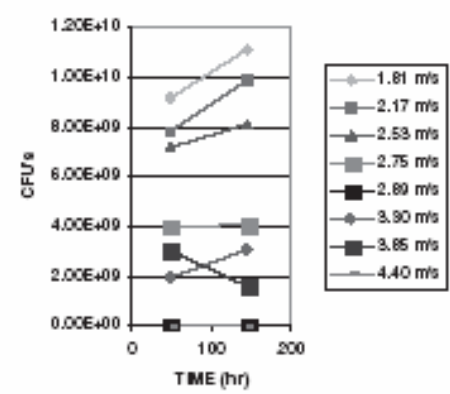

Figure 8 Total viable sesile bacteria on galvanized steel

\section{References}

Bryers, E. (1988). Modeling biofilm accumulation. In: Bazin, M. and Prosser, J.I. (eds.), Physiological models in microbiology. CRC Press. pp. 109-144.

Cloete, T.E., Jacobs, L. and Brözel, V.S. (1998). The chemical control of biofouling in industrial water systems. Biodegredation, Vol. 9, pp. 23-37.

Cloete, T.E. and Jacobs, L. (2001). Surfactants and the attachment of Pseudomonas aeruginosa to 3CR12 stainless steel and glass. Water $S A, 27(1)$, pp. 21-26.

Costerton, J.W., Lewandowski, Z., Caldwell, D.E., Korber, D.R. and Lappin-Scott, H.M. (1995). Microbial biofilms. Ann. Rev. Microbiol., Vol. 49, pp. 711-145.

Lawrence, J.R., Korber, D.R., Wolfaardt, G.M. and Caldwell, D.E. (1995). Behavioural strategies of surface-colonising bacteria. Adv. Microbiol. Ecol., Vol. 14, pp. 1-75. Peyton, B.M. (1996). Effects of shear stress and substrate loading rate on Pseudomonas aeruginosa biofilm thickness and density. Wat. Res., 30(1), pp. 29-33.

Trulear, B.E. and Characklis, W. (1982). Dynamics of biofilm processes. J. Wat. Pollut. Control Fed., 54(9), pp. 1288-1301.

Vieira, M.J., Melo, L.F. and Punheiro, M.M. (1993). Biofilm formation: hydrodynamic effects on internal diffusion and structure. Biofouling, Vol. 7, pp. 67-80.

Wolfaardt, G.M., Archibald, R.E.M. and Cloete, T.E. (1991). The use of DAPI in the quantification of sessile bacteria on submerged surfaces. Biofouling, Vol. 4, pp. 265-274.

Wolfaardt, G.M. and Cloete, T.E. (1992). The effect of some environmental parameters on surface colonization by microorganisms. Wat. Res., 26(4), pp.527-537. 